\title{
Health Organization in Republic of Macedonia-the place of preventive health care in the medical health system: advantages and disadvantages
}

\author{
Nikola Kamcev • Bistra Angelovska • \\ Gordana Kamceva $\cdot$ Kneginja Richter
}

Received: 31 May 2010 /Accepted: 19 July 2010/Published online: 14 August 2010

(C) European Association for Predictive, Preventive and Personalised Medicine 2010

\begin{abstract}
The health system in Macedonia is organized by public or private property health institutions divided on three levels: primary, secondary and tertiary health care. According to the legal regulations and their acts, regulatory authorities for preventive care are the health institutions of primary health care (whether they have private or public character), heath care establishments and some of the hospitals. In the period of transition starting from 1991 up to this day, numerous health system modifications have been made concerning health reforms: common alterations in health legislation change in property of health institutions, realignment of authorities etc. The adjustment of the system to the new circumstances and constant changes has provoked partial disruption in the established system for preventive health care activity.
\end{abstract}

Keywords Preventive health care $\cdot$ Health system . Health strategy $\cdot$ Health institutions $\cdot$ Public health

\section{Basic information}

Number of inhabitants in December 2008: 2048619 Average life expectancy: 73.76 years

Gross domestic product (GDP) per capita: 2 980.00\$

Unemployment rate: 32.4 [1]

N. Kamcev $\cdot$ B. Angelovska · G. Kamceva

Faculty of Medical Science, University "Goce Delcev"-Stip,

Štip, Macedonia

K. Richter $(\square)$

Klinik für Psychiatrie und Psychiatrie,

Klinikum Nuernberg,

Prof. Ernst-Nathan Str.1,

90419 Nuernberg, Germany

e-mail: Kneginja.Richter@gmx.de
Health expenses for 2006 ( $\%$ of GDP): 7.02\%

Causes of death, in general: circulatory system diseases - $57.3 \%$ of the total number of deceased, neoplasm's - $18.5 \%$, endocrine, nutritive, and metabolic diseases $-4.2 \%$ etc [2].

Organization of the health care system in the Republic of Macedonia: preventive health activity

Before the breakup of the SFR of Yugoslavia, there was no private medical practice in the health system of the Republic of Macedonia (considered as a member of the SFRY). All the citizens were included in the concept of national health or general health care in which the access to the health care services was available for everyone, medication was free of charge and health insurance was general and obligatory.

$\mathrm{Up}$ to 1991 the preventive medical activity was organized in the confines of the integrated public health sector through the organizational units in public health institutions with clearly defined assignments, authorities and designation.

With the radical upheaval in social organization after 1989, and the adoption of the liberal model of social organization, in which private property and market were dominating, the concept of health care is becoming insufficient and inappropriate to cover the concept of public health.

Today, the health system in Macedonian is organized by public or private property health institutions divided on three levels: primary, secondary and tertiary health care (Fig. 1).

In accordance with the Law on health care, the Law on health insurance and all acts for preventive care which resulted from these laws, authorized for health care are the 
Fig. 1 Health institutions authorized in preventive health care

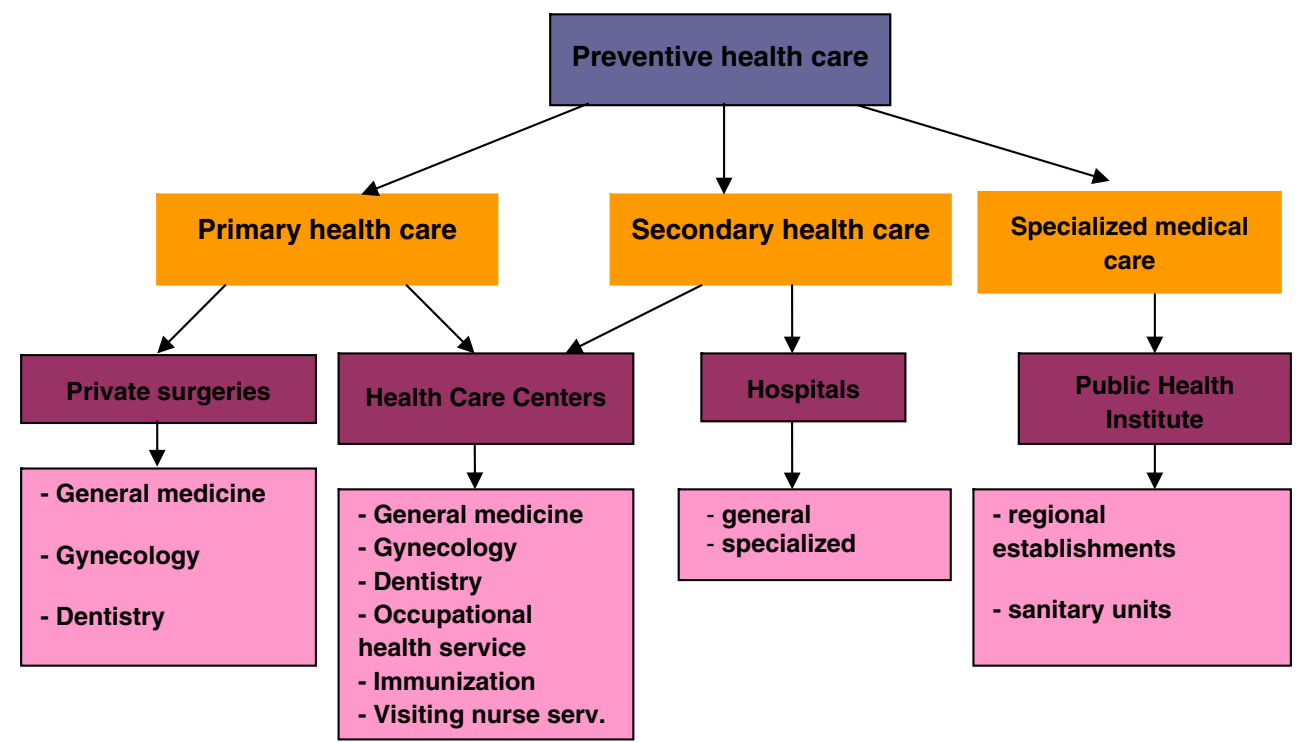

health institutions from the primary health care (whether they have private or public character), health care establishments and some of the hospitals [3].

The specialized care is realized through the National Health Care Center (Public Health Institute) in Skopje, regional health care centers and hygiene-epidemiological sanitary units. Visiting-nurse service (visits by nurses) also includes parts of the public health function (Table 1) [4].

The health system and implementation of health care in most part of Republic of Macedonia, with over $85 \%$, are financed by the Fund. The rest is financed from the state budget, various donations and direct payments made by patients for health services.

\section{Legislation and other published documents and analysis - emphasis on preventive health care activity}

Assembly of the Republic of Macedonia, the Government and the Ministry of Health set the legal framework for the functioning of the health system. Two major laws shape the health care system: health care law and the Law on health insurance [2]. From the time Macedonia gained independence, till today, all the important laws are passed from the field of health care that also cover preventive health care activity.

The passed laws and other acts correspond to the full extent to the reform processes of the health section and the recommendations from $\mathrm{WHO}$ and $\mathrm{EU}$ (Table 2: Overview of the fundamental acts that affect the organization of preventive health care activity).

However, their accomplishment is influenced by the period when they were passed, the constant alterations and the overlap of the authorities.
There are very few documents that have been issued since the period when the acts were passed until their implementation in present and which refer to the results of the utilization of the measures, the advantages and disadvantages of the preventive health activity. Some of them are presented in Table 3.

Table 1 Agreements of the Health Care Fund of Macedonia (HIF) with health care institutions that provide preventive health care [5]

Number of sealed contracts

\begin{tabular}{lr}
\hline Private clinics in PHC & 1,040 \\
General medicine & 118 \\
Gynecology & 85 \\
Pediatrics $^{\mathrm{a}}$ & 28 \\
Occupational health medicine $^{\mathrm{a}}$ & 13 \\
Medical practice for school children $^{\mathrm{a}}$ & 118 \\
Dentistry $^{\text {Polyclinics }}$ & 35 \\
Public health institutions of the PHC & \\
Health Care Centers & 34 \\
Public Health Facility & 3 \\
Public Health Care Institute & 1 \\
Regional HC Centers & 10
\end{tabular}

\footnotetext{
${ }^{\text {a }}$ For health care institutions from pediatrics, occupational health medicine and medical practice for school children there aren't any special preventive activities according to their specialty, but they provide health services as chosen family physician and they perform the preventive activity according to the contracts through fulfilling the goals

The Health Insurance Fund of Macedonia (HIF) is responsible for collecting and allocating funds from the obligated health insurance. Payment for provided services shall be made on the basis of sealed Contracts with health facilities (Table 1), under current legislation acts (Table 2)
} 
Table 2 Overview of the fundamental acts that affect the organization of preventive health care activity

Acts
Health Strategy of the Republic of Macedonia
in 2020 a reliable, efficient and equitable
health system [6]

Passed/altered

$02 / 2007$

in 2020 a reliable,
health system [6]

Strategic Plan 2009-2011 [7]

04/09

Law on health care [8]

1991 04/1997 (revised text)

Alterations: $02 / 02 ; 03 / 04 ; 10 / 05,12 /$ 05; 05/06;01/07;* 07/07;* 09/07;* 01/08;06/08; 05/09;

*decisions of the Constitutional Court

Health Insurance Act [9]

$03 / 2000$

Alterations: $11 / 2000 ; 05 / 03 ; 10 /$ $05 ; 12 / 05$ (revised text)

03/06;10/06;* 02/07;03/07; 06/07; * 07/07;* 07/08;01/09; 05/09;

*decisions of the Constitutional Court

2000

Book of rules for the contents and mode of realization of rights and engagements in obligatory health insurance [10]

Book of rules for payment of health services in primary health care [11]

Law on population protection from infectious diseases [12]

Alterations: 2001, 2001, 2002 and 2004

2001

Alteration: 2003

$10 / 04$
Declarations relating to preventive health care

It determines the vision to promote health and improve the health care system that meets the needs of the population.

Programs for health care and prevention, according to commitments of the strategy "Health for all in the 21 st century," WHO, the White Paper of the EU, the UN Millennium Goals and other international regulations and recommendations.

Defined strategic priorities and goals of the Ministry of Health 2009-2011.

It regulates the rights for health care to the citizens, relations and rights of health insurance, the procedure of using the health care and system and organization of health care.

Guarantees the right for preventive health care to insurers financed by funds from the HIF and to all citizens with funds provided by the State budget which are distributed by programs passed by the Government of Republic of Macedonia.

Authorized health care institutions for practicing preventive health care activity are the health care institutions from primary health care and the health care centers.

Despite the frequent alterations and supplements, the revised text is not published.

It regulates the health insurance of citizens, rights and obligations of health insurance, and the means of implementation of health insurance.

HIF covers the costs of preventive health care of insured citizens in primary health care and it partly bears the costs for financing the Programs for health care and prevention which are passed by the Ministry of Health.

The monitoring and control of execution of the objectives is the responsibility of the Health Insurance Fund and is executed on the basis of administrative data.

The law was passed nine years after the passing of the Law on health care, from which it resulted.

Despite the frequent alterations and supplements, the revised text is not published.

Sub-law act of the Law on health insurance.

Basic health care includes preventive measures and activities that will be realized in an extent and means determined by the programs.

District visit is accomplished by registered nurses from the team of the chosen doctor-gynecologist

Sub-law act on the Law on health insurance.

Appointing criteria for concluding contracts with health institutions and the manner of paying basic health services and those included in certain programs.

Payment: with a capitation ranging $60-70 \%$ of the capitation recompense as a fixed part and $30-40 \%$ variable part as a recompense for accomplishing preventive measures and activities.

Alterations: 11/08; 08/09
Appointing measures for population protection from infectious diseases.

Vaccination is done by a medical doctor in a health 
Table 2 (continued)

\begin{tabular}{lll}
\hline Acts & Passed/altered & Declarations relating to preventive health care \\
\hline & & $\begin{array}{l}\text { institution authorized by the Ministry of Health for doing } \\
\text { vaccination. } \\
\text { Ministry of Health superintends the utilization of this } \\
\text { law and the regulations based on it. } \\
\text { The Law was passed 13 years after the passing of the } \\
\text { Law on health care, from which it results. }\end{array}$ \\
Law on sanitary and health inspection [13] & $06 / 06$ & Alteration: $11 / 08$ \\
& $06 / 09$ & $\begin{array}{l}\text { Regulates the authorities of the state sanitary body of } \\
\text { inspectors for control over the accomplishment of the } \\
\text { preventive health care measures. } \\
\text { Arrangements on the basic functions and assignments on } \\
\text { public health, public health system, irregular public } \\
\text { health circumstances and financing of public health. }\end{array}$
\end{tabular}

Table 3 Preview on issued documents

Issued document $\quad$ Review on the preventive health activity

European Observatory on Health Systems and Policies WHO Regional Office for Europe www.euro.who.int/observator The former Yugoslav Republic of Macedonia, 2006 [4]

Ranks and judgments about the health reform in Republic of Macedonia made by the citizens, Project Coordination Unit-Ministry of Health/ World Bank, 29.01.2007 [3]

Revised final report, Thomas E. Novotny, Health Sector Management Project, Loan of IBRD number 4773 Component 1: Policy reform and implementation of the system of Public Health, Skopje, May 22.2008 [15]

Annual report on the results achieved in programs/subprograms of the strategic plan 2008-2010 for 2008, www.moh.gov.mk, Ministry of Health [16]

Report on the work of the State Sanitary and Health Inspectorate 2008, www.moh.gov.mk, Ministry of Health [17]

Health Insurance Fund of Macedonia, Annual Report 2008, Skopje, 2009 [5]
Preventive health care agencies in the Republic of Macedonia are successfully established and that results with an immunization that covers a great deal of the population.

On the basis of the total capacity of private surgeries and the needs of the customers of health services, private doctors from the primary health care do not provide full-scale primary health care that would comprise all preventive and emergency services after the end of the working hours.

In fact, they cannot provide continual health care in this period, which is essential for every health system.

It is a fact that Macedonian health is facing up to multiple problems of objective and subjective character that influence the quality of health care and directly affect customers' health services.

In the intention to get to a better quality for the health condition of the population, it is desirable that the main accent is put on the improvement of health, preventive and health culture augmentation with the population by the means of education and up-to-date information.

There is no assessment of national health accounts that accurately describe all medical expenses in Macedonia, funding of preventive programs is an object of reviewing in terms of distributions and priorities in the context of the project for the Basic package (which includes separation of clinical preventive services for key public health issues, from institutes).

Only some of the activities are quantified as achieved results in the field of preventive health protection and promotion of health in the area of the performance of activities projected by programs.

The data gathered from the controls which were made refers to the preformed vaccinations, the sanitary-hygienic conditions in buildings and facilities, the surveillance on outbreaks of the acute food poisoning, surveillance on prevention of occurrence and spread of infection diseases.

It's not specified how the realization of the objectives is controlled, which the detected irregularities are, and whether there are findings on the scope of the carried out prevention activities and the way of their monitoring. 
Advantages and disadvantages of the health system-the emphasis on preventive health activity

$>$ Health care in Macedonia is available to the population according to geographical, economic and weather factors, represented by a solid network of health care;

$>$ A Health strategy of the Republic of Macedonia 2020 is adopted to ensure efficient and equitable health system, which determines the vision to promote and improve the health system that meets the needs of the population, with clear strategic goals to improve preventive health care and strategic plan for its implementation;

$>$ The funding of the programs for preventive health care is mainly from funds from the central budget and the Health Insurance Fund;

$>$ Many of the laws and bylaws for the support of the strategic goals are being adopted;

$>$ In the Law of health care and legal acts, the indicators for success of implemented measures and preventive care programs are not defined as well as the control of laboratory tasks arising from it;

$>$ The frequent and inconsistent changes in key legislation without updating and publication of the revised text, as well as the overlapping of responsibilities of the institutions often lead to confusion and inappropriate use of them;

$>$ Interconnected regulations and bylaws adopted in a wide time period of a dozen years, leaving a space of action and significantly affect the overall quality of health care and in particular are affecting the preventive activity, given its specificity and social importance;

$\triangleright$ The structure of the health facilities with the enabled privatization has changed, thereby, the role of public health institutions has changed also (health centers and health stations) as a part of the leading institutions in the implementation of preventive health care;

$\triangleright$ Private primary health facilities have sufficient capacity to implement all measures provided by programs for preventive health care;

$\triangleright$ The monitoring, the control and the establishment of the measurable parameters of the carried preventive activities, are planned in several legal acts, where often competences are overlapping, but there is no clear act that would ensure the gathered data.

\section{Conclusion}

For improvement of preventive health care in Republic of Macedonia it is necessary to:

* Preparation of purified, clear and consistent legislation to provide preventive health care, with clearly defined responsibilities for operations and monitoring of the provided services;

* Providing adequate health network of public health institutions to establish departments responsible for implementing, monitoring and recording of the implemented activities from preventive health care;

* Providing regular and reliable system of financing for preventive health care and

* Taking measures to raise the health culture among the population with adequate promotion of public health.

\section{References}

1. Drzaven zavod za statistika "Makedonija vo brojki" str.12, Skopje, 2009.

2. Tozija F. и други, HEALTH of the nation of the Republic of Macedonia, Skopje, 2008.

3. Proektna edinica za koordinacija-Ministerstvo za zdravstvo/Svetska banka,Ocenki I stavovi na graganite za reformata na zdravstvoto vo Republika Makedonija, Skopje, 2007.

4. www.euro.who.int/observator, European Observatory on Health Systems and Policies WHO Regional Office for Europe, The former Yugoslav Republic of Macedonia, 2006.

5. Fond za zdravstveno osiguruvanje na Makedonija, Godisen izvestaj za 2008 godina, Skopje, 2009.

6. Ministerstvo za zdravstvo-Zdravstvena strategija na Republika Makedonija 2020 siguren, efikasen I pravicen zdravstven system, Skopje, fevruari 2007.

7. www.moh.gov.mk, Ministerstvo za zdravstvo,Strateski plan 20092011 godina na Ministerstvoto za zdravstvo, 02.04.2009.

8. Sobranie na Republika Makedonija, Zakon za zdravstvena zastita, Sl.vesnik na RM br. 38/91, 46/93, 55/95 i br. 5/2007.

9. Sobranie na Republika Makedonija, Zakon za zdravstveno osiguruvanje, Sl.vesnik na RM br. 25/2000 i br.18/2007.

10. Fond za zdravstveno osiguruvanje na Makedonija, Pravilnik za sodrzinata i nacinot na ostvaruvanjeto na pravata i obvrskite od zadolzitelnoto zdravstveno osiguruvanje. Sl. Vesnik na RM br. $111 / 2000,4 / 2001,71 / 2001,23 / 2002$ i 55/2004.

11. Fond za zdravstveno osiguruvanje na Makedonija, Pravilnik za plakanje na zdravstvenite uslugi vo primarnata zdravstvena zastita. Sl. Vesnik na RM br.48/2001, 31/2003.

12. Sobranie na Republika Makedonija, Zakon za zastita na naselenieto od zarazni bolesti, Sl.vesnik na RM br. 66/04.

13. Sobranie na Republika Makedonija, Zakon za sanittarnata I zdravstvenata inspekcija Sl.vesnik na RM br.71/06 i 139/08.

14. Sobranie na Republika Makedonija, Zakon za javno zdravje; S1. Vesnik na RM br.22 od 15.02.2010.

15. Novotni T., Revidiran konecen izvestaj vo ramkite na proektot za upravuvanje so zdravstveniot sector, Zaem na MBOR br.4733 Komponenta 1: Politiki I sproveduvanje Reforma na sistemot na javno zdravje, Ministerstvo za zdravstvo, Skopje, maj 2008.

16. www.moh.gov.mk, Ministerstvo za zdravstvo, Godisen izvestaj za ostvareni rezultati po program/podprogrami od strateski plan 2008-2010 za 2008.

17. Ministerstvo za zdravstvo, Izvestaj za rabotata na Drzavniot sanitaren I zdravstven inspektorat za 2008 godina, Skopje, 2009. 